\title{
Effect of Social Media Usage in Government Agencies' Communication Effort
}

\author{
Diana Dominic, Imelda Albert Gisip
}

To Link this Article: http://dx.doi.org/10.6007/IJARBSS/v11-i3/9277

DOI:10.6007/IJARBSS/v11-i3/9277

Received: 05 January 2021, Revised: 11 February 2021, Accepted: 27 February 2021

Published Online: 26 March 2021

In-Text Citation: (Dominic \& Gisip, 2021)

To Cite this Article: Dominic, D., \& Gisip, I. A. (2021). Effect of Social Media Usage in Government Agencies' Communication Effort. International Journal of Academic Research in Business and Social Sciences, 11(3), 1452-1467.

\section{Copyright: (C) 2021 The Author(s)}

Published by Human Resource Management Academic Research Society (www.hrmars.com)

This article is published under the Creative Commons Attribution (CC BY 4.0) license. Anyone may reproduce, distribute, translate and create derivative works of this article (for both commercial and non-commercial purposes), subject to full attribution to the original publication and authors. The full terms of this license may be seen at: http://creativecommons.org/licences/by/4.0/legalcode

Vol. 11, No. 3, 2021, Pg. 1452 - 1467

http://hrmars.com/index.php/pages/detail/IJARBSS

Full Terms \& Conditions of access and use can be found at http://hrmars.com/index.php/pages/detail/publication-ethics 


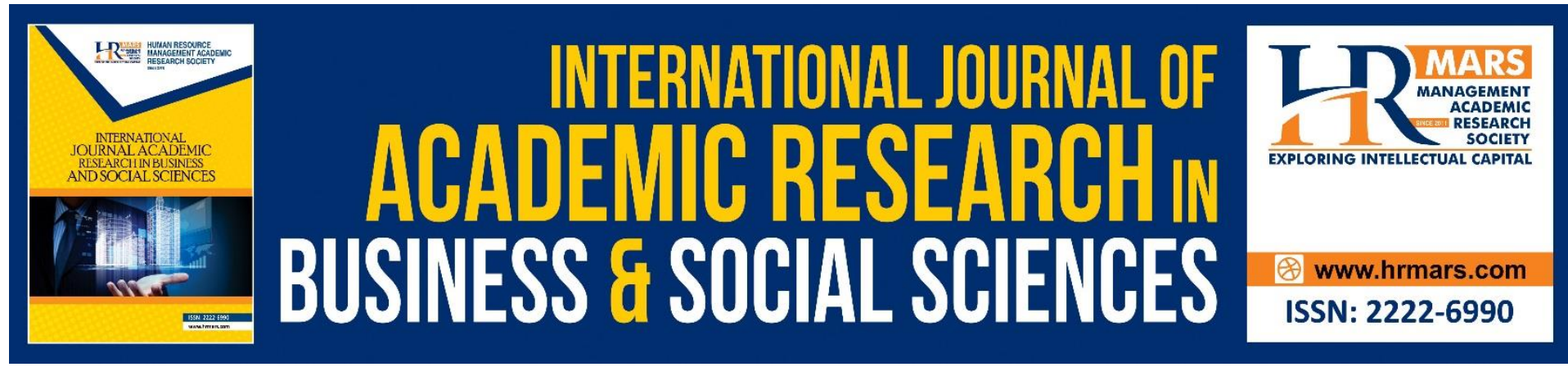

\title{
Effect of Social Media Usage in Government Agencies' Communication Effort
}

\author{
Diana Dominic, Imelda Albert Gisip \\ AAGBS, Universiti Teknologi Mara, Sabah, Malaysia
}

\begin{abstract}
The main objective of this study is to review the effect of the relationship between social media characteristics and users' continuance to use the govenment social media in disseminating information to the public. The conceptual part consists of an extensive search and analysis of academic articles and government publications related to government social media. This paper mainly based on secondary sources of information, through references and review of articles in selected journals on government social media. A conceptual framework has been proposed which links to the dimensions used from the past studies. The study highlights past studies on characteristics of government social media and the relationship of continuance to use the govenment social media. The review address the gaps from past studies. This study helps the government agencies to review the usage and effect of social media in government. This research will add to the existing literature reviews of government social media towards the communication effort in government agencies.
\end{abstract}

Keywords: Social Media, Government, Communication, Information, Public.

\section{Introduction}

Social media is a popular online platform that people use to build relationships. Beside socializing, social media is a medium to communicate and disseminating information. Malaysians spend five hours and 47 minutes a day on social media, with more than half the population regularly using it which ranking Malaysia top 5 highest in Southeast Asia in mobile social media 2019 (BERNAMA, 2019). About 78\% of the 32 million Malaysians are active users of social media and $97.3 \%$ are using Facebook as their main platform of social communication (MCMC, 2018). Social media is one of the extensions of static web 2.0 and has known as one of the medium connectivity for better communication, and people spend more time on the Internet visiting social media to gather information and to communicate with people (Karakiza, 2015).

Motivated by the efficiency, advancement and increasing use of technology by the private sector firms, social media applications have begun being adopted by government agencies to change the way of communication and their delivery of services to the public, especially in improving the performance, productivity and efficiency to the public (Androutsopoulou et al., 2019). Apart from that government provides 24/7 access information, forms and common transaction for the public. Use of social media, such as blogs, 
Facebook, YouTube and Twitter, is not just being empty chat rooms or just spending free time, but it is also a way for government leaders, in particular, to explore people's problems and to approach the community. Social media is now a network of extensive communication across all strata of society, regardless of whether adolescents, adults or leaders choose to use it. Government agencies around the world have been enthusiastic exploring the use of social media to promote citizen communication turning to crisis management. Social media applications have the possible way to improve the responsiveness, influence, effectiveness and also cost saving in public sector (Tagliacozzo \& Magni, 2018).

The use of social media during crisis are very significant in any natural disaster events, such as floods, wildfires, earthquakes, wars or tsunamis, information sharing is necessary (Aisha et al., 2015). Focusing on pandemic of Covid-19 which not only challenges the health system but also effect the whole world. In order to give information to the citizen about the covid-19 pandemic, government cannot rely on traditional methods of disseminating information in one way communication through television, radio, newspaper, flyers, public announcement through mobile do not seem effective (J. Park \& Cho, 2009). In Malaysia, the first announcement of movement control order (MCO)was made on the 16 March 2020 by Prime Minister which demand of banning on mass gathering for any activities (News Straits Times, 2020).

With the impose of MCO by the government, meant that restricted not only the movement but also the communication especially face-to-face of interaction. During confusion on the new pandemic people try to seek information and the alternative communication tool that they can use during the pandemic and social media is the most reliable medium where giving them two-way of communication and real-time response. Governments take fully advantages of social media to minimize mass panic, mix-ups, distress and anxiety (Chen et al., 2020). Due to social media characteristics such as openness, dialogism and engagement, it offers significant benefits in delivering information to the members of the public.

Throughout the COVID-19 pandemic, social media played an important role in disseminating information in most countries however it also linked to the blowout of misinformation (Teichmann et al., 2020; Thelwall \& Thelwall, 2020). Misinformation would cause chaotic circumstances and may damage the authenticity of the information (Tasnim et al., 2020). For example, hundreds of Iranian died after viral reports of remedy on COVID-19 by consuming alcohol intoxication it was spread on social media (BBC news, 2020). In Malaysia as of $24^{\text {th }}$ March 2020 the Quick Response Team has clarified 205 fake news spreading in social media, however the Minister of Communications and Multimedia has warned Malaysians to crisscross before sharing unverified news (Malaysiakini, 2020).

The COVID-19 Pandemic has made the government social media encountered unequalled public visits and public-seeking information especially on health communication. This study became unexpected attention and the method of transmitting the information through social media has been huge. News media such as live conference, direct messages and interactive interaction from health and government leaders played an important role. According to past researchers repeated giving information and statement has strong associate with the increase of trust in statement given (Teichmann et al., 2020). 
Hence, the main objective of this paper is to review the effect of social media usage in government agencies' communication effort from previous studies. This study attempts to explore the effect of government social media characteristics in process of improving the government disseminating information. As the effectiveness of social media depends on its use by individuals, it is therefore necessary for government agencies to consider and understand what factors affect the intention of an individual to use the social media.

The implementation of information technology such as social media on government can transform the service delivery especially on the communication. Current research discussed on use of social media in e-government has indicate of information quality (Zha et al., 2018), government transparency (Haro-de-Rosario et al., 2018), transparency (Porumbescu et al., 2020), participation (Baur, 2017) posted topic (Hofmann et al., 2013) and collaboration (Panagiotopoulos et al., 2014). This shows that social media can assist organizations to defend and strengthen their organization.

Despite many have showed a positive impact in many cases of using technology in transforming the government administration, however, past scholars revealed that many challenges in implementation of social media in government which affected the objectives to use the technology communication tool. Among the challenges facing by the government are lack of clear strategy (Sandoval-Almazan \& Gil-Garcia, 2012), the focus do not mainly identifying what public needs, overly focus on government not focus on the relationship among social media construct communication (Medaglia \& Zheng, 2017), and the biggest challenges facing by government social media at the moment is misinformation and fake news on social media (Allcott \& Gentzkow, 2017; Depoux et al., 2020; Tasnim et al., 2020). In overall government social media do not offer the clear-cut return on investment justification unlike businesses where they can choose their target customers.

In view of the challenges facing by government to improve the service delivery using the technology, scholars have come out with predictions factors that need to comprehend on government social media and how the characteristics of government social media have impact on the innovation of government communication (Hung et al., 2019; Mishaal \& AbuShanab, 2017; Sanina et al., 2017). On top of that, government also had views on the social media as innovation which also known as technology adoption (Feeney \& Welch, 2016).

\section{Literature Review}

\section{Effects Social Media Usage in Government Agencies}

The technology transformation and innovation outside the public sector are changing the expectation of the public towards the public administration service delivery (Mergel et al., 2019). Observing at the impact of social media to engage with the public, the government accepted social media in their practice following the open government around the world which first introduced by former US President Barrack Obama in 2008 during his first presidential campaign (Kim \& Lee, 2012; Mergel, 2016). Due to the fast growth and broad of benefits on social media become popular platform for government to disseminating information, interaction with the public as well as to achieve some goals such as public involvement, trust and improve the service quality in public administration (Criado et al., 2013). 
Using social media as a communication tool is cost saving and breaks the costly traditional media in government budget. The exclusion of middlemen like reporters and editors in conveying the government information could have reduced the manipulation or failing the deliverance of authentic government information (Arshad \& Khurram, 2020). According to Kuzma (2010), social technology can be transform the way government deliver the online information and service. However, only $30 \%$ of Asian government fully utilised the social media to communicate and disseminate information and this led to missed chances to better engage in greater community participation.

Social media is heavily used to increase public participant and helped to influence online users of social media site to change their perception towards the government. Apart from that, the goal is to inform the public, improve transparency and participation in government programs (Mergel, 2016). There are three main effects that many scholars used to predict the success of the government social media there are transparency, participation and collaboration (Abu-Shanab, 2015; Baur, 2017; Lee \& Kwak, 2012; Medaglia \& Zheng, 2017; Mergel, 2013a).

\section{Continuance use of Government Social Media}

Uses and gratification theory (U\&G theory) is the appropriate theory that can explain users' motivations towards the use of social media (Hsu et al., 2015). The intention to use the government social media platform shows a person's readiness to engage to the particular behaviour and it is considered antecedent reaction. The success of information system is depending on repeatedly use by the users. It is the same with social technology such as social media depends on the continued use of the platform rather than just accepting it because when individuals start using it, psychological motivations have an impact on their decision to continue use the platform (Basak \& Calisir, 2015; Bhattacherjee, 2001).

\section{Transparency}

Transparency usually related with trust in open government which first introduce by former US President Barack Obama in 2008 outlined transparency as one of the pillars in open government (John Carlo Bertot, Jaeger, \& Hansen, 2012). The definition of transparency may vary according to the subject matter but in this study transparency refers as the publicity of the government acts and its willingly providing relevant information to the member of the public (da Cruz et al., 2016). Past researchers found that there are mixed findings and even negative effect of transparency on trust. The result showing greater transparency associates with more trust, less trust, little and no effect at all (Grimmelikhuijsen et al., 2020).

\section{Participation}

Participation is one of the cores effects in determining the success of government social media. Online participation in social technology is different from participation in noninteractive websites which only provide information to the public (Abu-Shanab, 2015). The social media enable two-way of communication, change the public from inactive stakeholders to active society, increasing the participation and reforming the relationship between public and technology platform providers (John Carlo Bertot, Jaeger, \& Hansen, 2012; Medaglia \& Zheng, 2017; Mergel, 2013a). In online participation especially in social media allows interaction among government and the public for example posting comments on Facebook page, short messages on Twitter to blast breaking news and information. Public 
can directly give response and comments on the posting which encourage public share their opinions, discussions and comments in interactive communication. The participation technologies can be seen such as discussion forum, participating with online surveys or voting tools, education session and the engagements are broader (Mergel, 2016).

\section{Collaboration}

Starting with the online participation which allow the social technologies between government and public brings government to partner with the public through the decision making, identification of problem and finding solutions. In public sector, the relationship the government, people and organization working within the traditional bureaucracy interaction. The bureaucracy has made people are not keen to collaborate with the government because of information are restricted, law and policy constrain the people to connect with and limited in usage the information. This hierarchies have proven inefficient, unproductive, ineffective in many ways when it comes to finding for information (Mergel, 2019). However, by collaboration in online social network for government allowing government, organization and public to work collaboratively across agencies such as file sharing, government directory and search mechanisms that never existed before. This can reach the goal of bringing civilian agencies working together and making information easier through a single platform.

\section{Overview of Guiding Regulations and Directives for The Use of Social Media In The Malaysia Public Sector}

Table 1: Overview of regulations and directives usage social media in Malaysia Public Sector

\begin{tabular}{|c|c|c|c|}
\hline Title & $\begin{array}{c}\text { Date } \\
\text { Enacted }\end{array}$ & Description & Link \\
\hline $\begin{array}{l}\text { Official } \\
\text { Secrets Act } \\
1972 \\
\text { (Akta Rahsia } \\
\text { Rasmi 1972) }\end{array}$ & $\begin{array}{l}1 \text { October } \\
1972\end{array}$ & $\begin{array}{l}\text { Prohibiting the disseminating } \\
\text { information that classified as official } \\
\text { secret. }\end{array}$ & $\begin{array}{l}\text { http://www.agc.gov.m } \\
\text { y/agcportal/uploads/fil } \\
\text { es/Publications/LOM/E } \\
\text { N/Act\%2088.pdf }\end{array}$ \\
\hline $\begin{array}{l}\text { Communicati } \\
\text { ons and } \\
\text { Multimedia } \\
\text { Act } 1998\end{array}$ & 1998 & $\begin{array}{l}\text { An Act to provide for and to regulate } \\
\text { the converging communications and } \\
\text { multimedia industries, and for } \\
\text { incidental matters }\end{array}$ & $\begin{array}{l}\text { https://www.mcmc.gov } \\
\text {.my/en/legal/acts/com } \\
\text { munications-and- } \\
\text { multimedia-act-1998- } \\
\text { reprint-200 }\end{array}$ \\
\hline $\begin{array}{l}\text { Personal Data } \\
\text { Protection } \\
\text { Act } 2010\end{array}$ & June, 2010 & $\begin{array}{l}\text { An Act that regulates the processing } \\
\text { of personal data in regards to } \\
\text { commercial transactions. }\end{array}$ & $\begin{array}{l}\text { http://www.pdp.gov.m } \\
\text { y/index.php/my/ }\end{array}$ \\
\hline $\begin{array}{l}\text { MAMPU } \\
\text { Director } \\
\text { General's } \\
\text { Instruction } \\
\text { Letter } 17 \text { July } \\
2009 \text { entitled } \\
\text { "Blog } \\
\text { Implementati }\end{array}$ & $\begin{array}{ll}17 & \text { July } \\
2009 & \end{array}$ & $\begin{array}{l}\text { Aims to ensure that all agencies of } \\
\text { government enhance their use of the } \\
\text { internet as a resource of interacting }\end{array}$ & $\begin{array}{l}\text { https://www.mampu.g } \\
\text { ov.my/en/circulars/cat } \\
\text { egory/85-directives-of- } \\
\text { the-director-general-of- } \\
\text { mampu }\end{array}$ \\
\hline
\end{tabular}




\begin{tabular}{|c|c|c|c|}
\hline $\begin{array}{l}\text { on for Public } \\
\text { Sector } \\
\text { Agencies" }\end{array}$ & & & \\
\hline $\begin{array}{l}\text { MAMPU } \\
\text { Director } \\
\text { General's } \\
\text { Instruction } \\
\text { Letter dated } \\
19 \text { November } \\
2009 \text { "The } \\
\text { Use of Social } \\
\text { Media in the } \\
\text { Public Sector" }\end{array}$ & $\begin{array}{l}19 \\
\text { November } \\
2009\end{array}$ & $\begin{array}{l}\text { Establishes guidelines for the best } \\
\text { practices use of social media in the } \\
\text { public sector }\end{array}$ & $\begin{array}{l}\text { https://www.mampu.g } \\
\text { ov.my/en/circulars/cat } \\
\text { egory/85-directives-of- } \\
\text { the-director-general-of- } \\
\text { mampu }\end{array}$ \\
\hline $\begin{array}{l}\text { MAMPU } \\
\text { Director } \\
\text { General's } \\
\text { Instruction } \\
\text { Letter dated } 8 \\
\text { April } 2011 \\
\text { entitled "Best } \\
\text { Practices for } \\
\text { the Use of } \\
\text { Social } \\
\text { Network } \\
\text { Media in the } \\
\text { Public Sector" }\end{array}$ & $\begin{array}{ll}8 & \text { April } \\
2011 & \end{array}$ & $\begin{array}{l}\text { Outlines specific action on federal } \\
\text { agencies should take in implementing } \\
\text { the social media in the Public Sector. }\end{array}$ & $\begin{array}{l}\text { https://www.mampu.g } \\
\text { ov.my/en/circulars/cat } \\
\text { egory/85-directives-of- } \\
\text { the-director-general-of- } \\
\text { mampu }\end{array}$ \\
\hline
\end{tabular}




\section{Communication Effort in Government Social Media}

Table 2: The dimension and gaps of Communication Effort in government social media in Literature

\begin{tabular}{|c|c|c|c|}
\hline No & Author, Year & Dimensions & Gaps \\
\hline 1. & Mergel (2012) & $\begin{array}{l}\text { a. Transparency } \\
\text { b. Participation } \\
\text { c. Collaboration }\end{array}$ & $\begin{array}{l}\text { Limited measurement social } \\
\text { media communication in } \\
\text { government. }\end{array}$ \\
\hline 2. & $\begin{array}{l}\text { Hofmann et al., } \\
(2013)\end{array}$ & $\begin{array}{l}\text { a.Topics post } \\
\text { b.Frequency } \\
\text { c. Citizen Reaction }\end{array}$ & $\begin{array}{l}\text { Insufficiently addressed on what } \\
\text { make government social media } \\
\text { successful. }\end{array}$ \\
\hline 3. & $\begin{array}{l}\text { A.Mishaal \& Abu- } \\
\text { Shana, (2015) }\end{array}$ & $\begin{array}{l}\text { a. Transparency } \\
\text { b. Participation } \\
\text { c. Collaboration } \\
\text { d. Comfort } \\
\text { f. Posted post }\end{array}$ & $\begin{array}{l}\text { There is a communication } \\
\text { problem between government } \\
\text { and the stakeholders. }\end{array}$ \\
\hline 4. & Sanina et al., (2017) & $\begin{array}{l}\text { a. Reliability } \\
\text { b.Speed } \\
\text { c. Effectiveness }\end{array}$ & $\begin{array}{l}\text { Lack of understanding of how } \\
\text { government and business } \\
\text { communication pose risks for } \\
\text { the success. }\end{array}$ \\
\hline 5. & Hung et al., (2019) & $\begin{array}{l}\text { a. Communication } \\
\text { quality } \\
\text { b. Responsiveness }\end{array}$ & $\begin{array}{l}\text { Lack of empirical study in } \\
\text { government social media }\end{array}$ \\
\hline
\end{tabular}

From the table 2 above, it can see that there are still lacks understanding in use of social media particularly in communication effort in public sector. Most of the dimension used in the past studies are about the transparency, participation, collaboration, posted topic, the effectiveness, communication quality, responsiveness, speed, frequency and public reactions. These are among the factors that influence the communication effort to government social media studied by previous researchers. Research on government communication is generally limited at best (Abdelsalam et al., 2013; Hofmann et al., 2013). In the context of Malaysia, study on the government social media is still low (Wok \& Mohamed, 2017). Most studies adopted from western countries which may not suitable for local culture (Rahman et al., 2017). 


\section{Related Literature and Research Gaps}

Table 3 Selected previous studies on the adoption of Government social media

\begin{tabular}{|c|c|c|c|}
\hline Year & Author & Findings and Effects & Gaps \\
\hline 2010 & $\begin{array}{l}\text { John C. Bertot } \\
\text { et al., }\end{array}$ & $\begin{array}{l}\text { Social media can have potentially anti- } \\
\text { corruption. }\end{array}$ & $\begin{array}{l}\text { Understanding user needs, } \\
\text { behaviours, and } \\
\text { expectations of people's } \\
\text { needs to social media and } \\
\text { government services. }\end{array}$ \\
\hline
\end{tabular}

2012 John Carlo Social media can affect the The role of social media Bertot et al., transformation of the way people technologies in government communicate with governments. information services are still coalescing, need time to analyze and research of social media.

2012 Magro

Encouraged for e-participation into administering action using a new social media.

2013 Hofmann et al.,

2014 Khan et al.,
Social media in government enable citizens to gain easier access to government and be more informed as well as heightening their perception of transparency in government.
The lack of a tangible goal for e-government, change is still needed in government culture before broad sustainable success can be achieved in the use of social media.

Many governments lack the capability to communicate with other governmental organizations and the public effectively.

Focus on addressing the needs of the people and not merely increasing the number of followers and formulating social media strategies to control their approach in attracting people's participation.

Previous research did not test the relationship between e-government and transparency. 


$2016 \quad$ Guo et al., $\quad \begin{aligned} & \text { The operators of government social } \\ & \text { media should focus on meeting user } \\ & \text { needs. }\end{aligned}$

2017 Sanina et al., It is the responsibility of the government to understand and utilize the most appropriate communication channels to maximize the communicative results.

2018 Park \& Lee

2019 Hung et al.,
Trust in government information are primary determinants of willingness to accept the new application and intention to use it.

The antecedent of perceived usefulness has a positive effect on continuance intention.
Extend the study of user behaviour to the context of social media platforms and identify the gratification factors that motivate user to participate in government social media.

There is very limited
research on how from a
technical or formal point on
communication should be
efficiently organized.

The use of communication technology is still a new area of study.

Very little evidence has been made for how the nature of communication meets user expectation for continued engagement on government social media platforms.

From the table 3 above there are still have need to conduct the study on government social media.

\section{Research Hypothesis}

The government social media critical success framework is built to propose that the government social media characteristics have positive and direct impact on the success of government social media transparency is expected to increase the continuance usage of government social media. To understand the relationship each characteristic, the following hypotheses were set up to be tested. According to Mergel 2013, transparency, participation and collaboration involvement in government social media are significantly has a relationship to the success of communication (Mergel, 2013c). Abu-Shanab, 2015 also revealed that these factors give a high impact and also gives a positive significant effect on critical success of government social media (Abu-Shanab, 2015).

\section{Relationship between Transparency and Continuance to use}

Government transparency can be seen as one of the keys to better administration of governance to help prevent corruption and enhance government performance (S. Grimmelikhuijsen et al., 2013). The previous studies on citizens satisfaction towards government found that if the public believed the e-government transparent, they were more likely to come back to the site and use the site, and showed trust in the government by 
communicating with the government through its social media. In a nutshell, the higher the transparency, the higher the continuance to use the government social media (A.Mishaal \& Abu-Shana, 2015; Kim \& Lee, 2012). Therefore, this study hypothesized that:

$\mathrm{H} 1$ : Transparency has a positive effect on continuance to use the government social media

\section{Relationship between participation and continuance to use}

The government should encourage the public to participate in government dialogues and discussions (Mishaal \& Abu-Shanab, 2017). Participation is most often mentioned to be vital for social media public engagement. For example, social media channels are used to attract people to respond to online surveys on the content provided. In addition to providing information to the public, the agencies are actively seeking feedback from the people through their social media channels. Feedback is used to improve the quality of policy, decision, or final document (Mergel, 2013b). Therefore, the study hypothesized that:

H2 : Participation has a positive effect on the Continuance to use government social media.

\section{Relationship between collaboration and continuance to use}

Collaboration between the government and the people shows an even higher level of involvement through the relationship, which is associated with allowing the audience to stay engaged with the government content and created co-op government innovations. Therefore, collaborative engagement is only identified in the active interaction of the people with the government-supplied content (Bonsón et al., 2015; Mergel, 2013a).

Therefore, the study hypothesized that:

H3 : Collaboration has a positive effect on the Continuance to use government social media

\section{Proposed Conceptual Model}

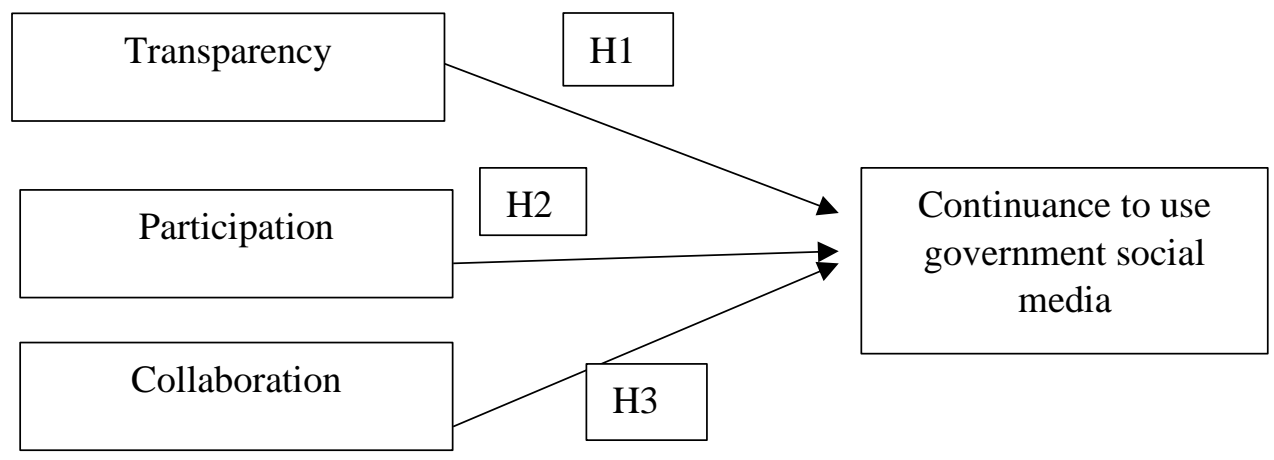

Source: Author's own

Figure 1: Presents the proposed conceptual model critical success factors on government social media.

Based on the literature review before, there are previous studies investigating on government social media but there are few empirical studies that focusing on government social media on disseminating information. Previous studies stated that there are still lack of studies on government social media to explore (Arshad \& Khurram, 2020; John Carlo Bertot, Jaeger, \& Hansen, 2012; Mergel, 2013a). In addressing the problems, the author proposes to analyse 
the effect of government social media characteristics to continuance to use government social media.

\section{Conclusion and Discussion}

This study analysed literature to better understand the social media landscape and its role in e-government communication performance to better understanding of the relationship between the government social media characteristics and continuance to use the social media platform. The literature section also discusses the significance of social media as a communication tool and the factors that lead governments to implement it in their communication. Some models of social media-based e-government and the strategies of governments implemented to interact through social media are also examined.

The benefits of social media also have been discussed in literature review to give clear idea why government should adopt social media. This study is expected to help researchers and practitioners in communication industry to improve the understanding and identify the opportunities for improvements. The communication result will demonstrate whether the government is able to collect information and get involvement from the public using the medium of social media.

The research hypothesis is being developed from previous studies and the proposed research model. This study will be conducted based on the proposed conceptual model. The contribution of this study is to propose a framework that included the three factors of prediction on continuance to use the government social media in the context of Malaysian government. Thus, it gives the benefits, opportunities and recommendations for future researchers to explore in more factors that contribute the success of communication.

The use of social media among government agencies has not been adequately researched especially in developing countries such as Malaysia. The purpose of this study is to develop conceptual framework for adaption of social media among the government agencies. The study is based on the theory of uses and gratification theory and open government model and proposed a modification in order to fit with the model in a conceptual framework of government social media. This study contributes to the literature by adding a new conceptual framework in order to fill the gaps in the literature. In a future, this study would empirically validate major limitations of the proposed conceptual framework.

\section{Acknowledgement}

The researchers would like to acknowledge Kaizen Trenovation for the opportunity to present the paper in International Conference on Social Science, Technology, Education and Management (CSTEM 2020) and Universiti Teknologi MARA, Sabah Branch Malayisa.

\section{Corresponding Author}

Diana Dominic

A DBA candidate of Arshad Ayub Graduate Business School, Universiti Teknologi MARA, Sabah Branch. Malaysia

Email: diana0773dba@gmail.com 


\section{References}

Mishaal, D., \& Abu-Shana, E. b. (2015). The Effect of Using Social Media in Governments: Framework of Communication Success. May, 357-364.

Abdelsalam, H. M., Reddick, C. G., Gamal, S., \& Al-shaar, A. (2013). Social media in Egyptian government websites: Presence, usage, and effectiveness. Government Information Quarterly, 30(4), 406-416.

Abu-Shanab, E. A. (2015). Reengineering the open government concept: An empirical support for a proposed model. Government Information Quarterly, 32(4), 453-463.

Aisha, T. S., Wok, S., Manaf, A. M. A., \& Ismail, R. (2015). Exploring the Use of Social Media During the 2014 Flood in Malaysia. Procedia - Social and Behavioral Sciences, 211(September), 931-937.

Allcott, H., \& Gentzkow, M. (2017). Social media and fake news in the 2016 election. Journal of Economic Perspectives, 31(2), 211-236.

Androutsopoulou, A., Karacapilidis, N., Loukis, E., \& Charalabidis, Y. (2019). Transforming the communication between citizens and government through Al-guided chatbots. Government Information Quarterly, 36(2), 358-367.

Arshad, S., \& Khurram, S. (2020). Can government's presence on social media stimulate citizens' online political participation? Investigating the influence of transparency, trust, and responsiveness. Government Information Quarterly, 37(3), 101486.

Basak, E., \& Calisir, F. (2015). An empirical study on factors affecting continuance intention of using Facebook. Computers in Human Behavior, 48, 181-189.

Baur, A. W. (2017). Harnessing the social web to enhance insights into people's opinions in business, government and public administration. Information Systems Frontiers, 19(2), 231-251.

BBC news. (2020). Coronavirus: The human cost of virus misinformation - BBC News. BBC News. https://www.bbc.com/news/stories-52731624

BERNAMA. (2019). Malaysia ranks top 5 globally in mobile social media penetration, highest in region. News Straits Times (NST). https://www.nst.com.my/lifestyle/bots/2019/01/456119/malaysia-ranks-top-5globally-mobile-social-media-penetration-highest

Bertot, J. C., Jaeger, P. T., \& Grimes, J. M. (2010). Using ICTs to create a culture of transparency: E-government and social media as openness and anti-corruption tools for societies. Government Information Quarterly, 27(3), 264-271.

Bertot, J. Carlo, Jaeger, P. T., \& Grimes, J. M. (2012). Promoting transparency and accountability through ICTs, social media, and collaborative e-government. Transforming Government: People, Process and Policy, 6(1), 78-91.

Bertot, J. C., Jaeger, P. T., \& Hansen, D. (2012). The impact of polices on government social media usage: Issues, challenges, and recommendations. Government Information Quarterly, 29(1), 30-40.

Bhattacherjee, A. (2001). An empirical analysis of the antecedents of electronic commerce service continuance. Decision Support Systems, 32(2), 201-214.

Bonsón, E., Royo, S., \& Ratkai, M. (2015). Citizens' engagement on local governments' facebook sites. an empirical analysis: The impact of different media and content types in western europe. Government Information Quarterly, 32(1), 52-62.

Chen, Q., Min, C., Zhang, W., Wang, G., Ma, X., \& Evans, R. (2020). Unpacking the black box: How to promote citizen engagement through government social media during the COVID-19 crisis. Computers in Human Behavior, 110(March), 106380. 
Criado, J. I., Sandoval-Almazan, R., \& Gil-Garcia, J. R. (2013). Government innovation through social media. Government Information Quarterly, 30(4), 319-326.

da Cruz, N. F., Tavares, A. F., Marques, R. C., Jorge, S., \& de Sousa, L. (2016). Measuring Local Government Transparency. Public Management Review, 18(6), 866-893.

Depoux, A., Martin, S., Karafillakis, E., Preet, R., Wilder-Smith, A., \& Larson, H. (2020). The pandemic of social media panic travels faster than the COVID-19 outbreak. Journal of Travel Medicine, 27(3), 1-2.

Feeney, M. K., \& Welch, E. W. (2016). Technology-Task Coupling:Exploring Social Media Use and Managerial Perceptions of E-Government. The American Review of Public Administration, 46(2), 162-179.

Grimmelikhuijsen, S. G., Piotrowski, S. J., \& Van Ryzin, G. G. (2020). Latent transparency and trust in government: Unexpected findings from two survey experiments. Government Information Quarterly, 37(4), 101497.

Grimmelikhuijsen, S., Porumbescu, G., Hong, B., \& Im, T. (2013). The Effect of Transparency on Trust in Government. Public Administration Review, 73(4), 575-586.

Guo, J., Liu, Z., \& Liu, Y. (2016). Key success factors for the launch of government social media platform: Identifying the formation mechanism of continuance intention. Computers in Human Behavior, 55, 750-763.

Haro-de-Rosario, A., Sáez-Martín, A., \& del Carmen Caba-Pérez, M. (2018). Using social media to enhance citizen engagement with local government: Twitter or Facebook? New Media and Society, 20(1), 29-49.

Hofmann, S., Beverungen, D., Räckers, M., \& Becker, J. (2013). What makes local governments' online communications successful? Insights from a multi-method analysis of Facebook. Government Information Quarterly, 30(4), 387-396.

Hsu, M. H., Tien, S. W., Lin, H. C., \& Chang, C. M. (2015). Understanding the roles of cultural differences and socio-economic status in social media continuance intention. Information Technology and People, 28(1), 224-241.

Hung, S. Y., Chen, K., \& Su, Y. K. (2019). The effect of communication and social motives on Egovernment services through social media groups. Behaviour and Information Technology, 3001(May), 1-17.

Karakiza, M. (2015). The Impact of Social Media in the Public Sector. Procedia - Social and Behavioral Sciences, 175, 384-392.

Khan, G. F., Yoon, H. Y., \& Park, H. W. (2014). Social media communication strategies of government agencies: Twitter use in Korea and the USA. Asian Journal of Communication, 24(1), 60-78.

Kim, S., \& Lee, J. (2012). E-Participation, transparency, and trust in local government. Public Administration Review, 72(6), 819-828.

Kuzma, J. (2010). Asian Government Usage of Web 2.0 Social Media. European Journal of EPractice, 9, 1-13.

Lee, G., \& Kwak, Y. H. (2012). An Open Government Maturity Model for social media-based public engagement. Government Information Quarterly, 29(4), 492-503.

Magro, M. J. (2012). A Review of Social Media Use in E-Government. Administrative Sciences, 2(2), 148-161.

Malaysiakini. (2020). Communications Ministry's Quick Response Team clarified 205 fake news since inception. https://www.malaysiakini.com/news/521875

MCMC. (2018). Internet-Users-Survey-2018 mcmc.

Medaglia, R., \& Zheng, L. (2017). Mapping government social media research and moving it 
forward: A framework and a research agenda. Government Information Quarterly, 34(3), 496-510.

Mergel, I. (2012). The social media innovation challenge in the public sector. Information Polity, 17(3-4), 281-292.

Mergel, I. (2013a). A framework for interpreting social media interactions in the public sector. Government Information Quarterly, 30(4), 327-334.

Mergel, I. (2013b). Social media adoption and resulting tactics in the U.S. federal government. Government Information Quarterly, 30(2), 123-130.

Mergel, I. (2013c). SOCIAL MEDIA IN THE PUBLIC SECTOR (First Edit). Jossey- Bass.

Mergel, I. (2016). Social media institutionalization in the U.S. federal government. Government Information Quarterly, 33(1), 142-148.

Mergel, I. (2019). Digital service teams in government. Government Information Quarterly, 36(4), 101389.

Mergel, I., Edelmann, N., \& Haug, N. (2019). Defining digital transformation: Results from expert interviews. Government Information Quarterly, 36(4), 101385.

Mishaal, D. A., \& Abu-Shanab, E. A. (2017). Utilizing Facebook by the Arab World Governments. International Journal of Public Administration in the Digital Age, 4(3), 5378.

News Straits Times. (2020). 14-day Movement Control Order begins nationwide on Wednesday. $\quad$ https://www.nst.com.my/news/nation/2020/03/575180/14-daymovement-control-order-begins-nationwide-wednesday

Panagiotopoulos, P., Bigdeli, A. Z., \& Sams, S. (2014). Citizen-government collaboration on social media: The case of Twitter in the 2011 riots in England. Government Information Quarterly, 31(3), 349-357.

Park, H., \& Lee, T. (David). (2018). Adoption of E-Government Applications for Public Health Risk Communication: Government Trust and Social Media Competence as Primary Drivers. Journal of Health Communication, 23(8), 712-723.

Park, J., \& Cho, K. (2009). Declining Relational Trust between Government and Publics, and Potential Prospects of Social Media in the Government Public Relations. Proceedings of EGPA Conference 2009 The Public ..., April, 1-18. http://www.egpa2009.com/documents/psg1/ParkCho.pdf

Porumbescu, G. A., Cucciniello, M., \& Gil-Garcia, J. R. (2020). Accounting for citizens when explaining open government effectiveness. Government Information Quarterly, 37(2).

Rahman, N. A. A., Hassan, M. S. H., Osman, M. N., \& Waheed, M. (2017). Research on the State of Social Media Studies in Malaysia : 2004-2015. Jurnal Komunikasi : Malaysian Journal of Communication, 33(4), 38-55.

Sandoval-Almazan, R., \& Gil-Garcia, J. R. (2012). Are government internet portals evolving towards more interaction, participation, and collaboration? Revisiting the rhetoric of egovernment among municipalities. Government Information Quarterly, 29(SUPPL. 1), S72-S81.

Sanina, A., Balashov, A., Rubtcova, M., \& Satinsky, D. M. (2017). The effectiveness of communication channels in government and business communication. Information Polity, 22(4), 251-266.

Song, C., \& Lee, J. (2016). Citizens Use of Social Media in Government, Perceived Transparency, and Trust in Government. Public Performance and Management Review, 39(2), 430-453.

Tagliacozzo, S., \& Magni, M. (2018). Government to Citizens (G2C) communication and use of 
social media in the post-disaster reconstruction phase. Environmental Hazards, 17(1), 120.

Tasnim, S., Hossain, M. M., \& Mazumder, H. (2020). Impact of rumors or misinformation on coronavirus disease ( COVID-19) in social media Coronavirus disease ( COVID-19) and flow of ( mis ) information in social media. School of Public Health, Texas A\&M University, 8.

Teichmann, L., Nossek, S., Bridgman, A., \& Loewen, P. (2020). Public Health Communication and Engagement on Social Media during the COVID-19 Pandemic. https://osf.io/7hypj/download

Thelwall, M., \& Thelwall, S. (2020). Retweeting for COVID-19: Consensus building, information sharing, dissent, and lockdown life.

Wok, S., \& Mohamed, S. (2017). Internet and Social Media in Malaysia: Development, Challenges and Potentials. The Evolution of Media Communication.

Zha, X., Yang, H., Yan, Y., Liu, K., \& Huang, C. (2018). Exploring the effect of social media information quality, source credibility and reputation on informational fit-to-task: Moderating role of focused immersion. Computers in Human Behavior, 79, 227-237. 